\title{
Isolation, Cloning and Expression of Insecticidal-Protein-Encoding Gene $t c d A$ from Photorhabdus luminescens in Escherichia coli
}

\author{
S.R. Mulla ${ }^{1}$, Shourabh Joshi ${ }^{2} *$ and Joy Das $^{2}$ \\ ${ }^{1}$ Department of Biotechnology and Crop improvement, University of \\ Horticultural Science, Bagalkot-587103, India \\ ${ }^{2}$ Department of Biotechnology, University of Agricultural Sciences, \\ GKVK, Bangalore -560065, Karnataka, India \\ *Corresponding author
}

A B S T R A C T

\begin{abstract}
Keywords
tcdA, Photorhabdus

luminescens,

Cloning and

expression.

Article Info

Accepted:

21 July 2017

Available Online:

10 September 2017

In this study, the tcdA coding gene of Photorhabdus luminescens was inserted in pET32a (+) plasmid with extra His-tag sequence. Photorhabdus luminescens strain was isolated from Western Ghats of Karnataka, which is symbiotically associated with entomopathogenic nematode Heterorhabditis spp. The DNA sequence of cloned toxin gene $(7551 \mathrm{bp})$ has an open reading frame encoding 2506 amino acids with a predicted molecular mass of $283 \mathrm{kDa}$. The integrity of the constructed plasmid was confirmed using restriction digestion and PCR. The $t c d A$ gene was expressed after induction with IPTG in Escherichia coli BL21. Recombinant $t c d A$ was purified by Ni- NTA Affinity Chromatography.
\end{abstract}

\section{Introduction}

Entomopathogenic nematodes can provide effective biological control of several important soil insect pests that occur in cryptic habitats (Georgis and Manweiler, 1994; Koppenhofer, 2000). Favorable characteristics include formation of a durable infective stage that can be stored for long periods and applied by conventional methods, and persistence in the environment following application. In addition, these beneficial nematodes are specific to insects, safe to nontarget organisms including humans other vertebrates and plants, they do not pollute the environment (Poinar, 1990; Ehlers, 1991). Accordingly, there is an intense interest to isolate these nematodes from different regions of the world that are climatically adapted and have the potential for biological control of pests in that area.

Bacteria of the genera Photorhabdus and Xenorhabdus form a mutually beneficial symbiotic complex with the entomopathogenic nematodes (EPNs) in the families' Heterorhabditidae and Steinernematidae respectively which are able to infect kill and reproduce in many insect species (Boemare et al., 1993; Thomas and Poinar, 1983). In this mutualistic relationship the bacteria are necessary to kill insect hosts and for nematode development within the insect (Boemare et al., 1993; Boemare, 2002). 
The bacteria are transported by the free-living infective juvenile (IJ) stage of the EPN being located in the anterior part of the Heterorhabditis intestine or in a special intestinal vesicle in most of the Steinernema spp. (Bird and Akhurst, 1983; Martens and Goodrich-Blair, 2005). Although these bacteria might survive in soil for 1 week in the absence of the nematode (Morgan et al., 2001) in natural conditions the IJs act as active vectors that survive in soil until they find a suitable host.

The toxin complex (tc) genes of Photorhabdus encode insecticidal high molecular weight Tc toxins. These toxins have been suggested as useful supplement or offer an alternative to those derived from Bacillus thuringiensis for expression in insect-resistant transgenic plants. However, tca and tcc loci encode for several open reading frames (ORFs) (Ffrench-Constant et al., 2003), thus producing multiple components per locus; $t c b$ and $t c d$ are comprised of a single long ORF. The toxin complexes (Tcs) are encoded by the PAI I (pathogenicity island I) (Waterfield et al., 2004) and have been identified as high molecular weight insecticidal toxins comprised of multiple subunits (FfrenchConstant et al., 2007). There are four such complexes, namely $t c a, t c b, t c c$ and $t c d$, found in different loci.

The three complexes show significant similarity to one another; therefore three basic types of genetic elements have been identified: the $t c d A$-like element, equivalent to the combination of $t c a A$ and $t c a B$, the $t c d B$ like element, equivalent to the $t c a C$ and the tcc $C$-like element. $t c d A$-like elements are responsible for establishing primary toxicity, while the $t c d B / t c c C$-like elements are potentially toxic (Pinheiro and Ellar, 2007), $t c b \mathrm{~A}$ and $t c d \mathrm{~A}$ also share 50 percent identity overall, as well as a similar predicted pattern of both carboxy- and amino-terminal cleavage. It was postulated that these proteins might thus be homologs (to some degree) of one another. Furthermore, the similar, large size of $t c b \mathrm{~A}$ and $t c d \mathrm{~A}$, and also the fact that both toxins appear to act on the gut of the insect, may suggest similar modes of action (Ffrench-Constant and Bowen, 1999). Against sensitive insects, the potency of toxin A compares favorably with published values for Bt toxins (Liu et al., 2003) and therefore, we chose to study toxin A, looking at its importance in the field of agriculture, In this study, the Photorhabdus luminescens tcdA gene has been cloned, expressed in Escherichia coli (E. coli) BL21 and purified.

\section{Materials and Methods}

\section{Bacterial strains}

Photorhabdus luminescens strain was isolated from western ghat of Karnataka, which is symbiotically associated with entomophagous nematode Heterorhabditis. Standard culture of Photorhabdus luminescens was obtained from ICGEB. Escherichia coli strain was used for cloning, and maintenance of different DNA fragments. A prokaryotic expression vector pET32a (+) (Novagene) was used for recombinant protein production.

The recombinant plasmid was transformed into E. coli, BL21 as host strain. LB broth or LB agar was supplemented when required with $100 \mu \mathrm{g} / \mathrm{mL}$ ampicillin. All chemicals were purchased from Himedia.

DNA extraction protocol was followed according to Sambrook et al., (1989). Total DNA isolated was quantified by following the ethidium bromide spotting method as given by Sambrook and Russel (2001).

\section{Designing of primers}

Primer pairs were designed to amplify the full-length region of $t c d A$ gene and primers 
were also designed to amplify the internal regions of the $t c d A$ gene. From the sequence information available in NCBI database (accession number AF188483). Primers were designed using Fast-PCR software and were synthesized from Sigma Genset, Germany

\section{Full length primer for $t c d A$}

Forward primer with $\mathrm{Bam} \mathrm{H}$ I site for cloning into pET32a

5 'ctcacgcggatccttatttaatggtgtagcgaatatgc (38mer) Reverse primer with Xho I site for cloning into pET32a (+) 5'gtgcagctcgagttatttaatggtgtagcgaatatgc (37mer).

Internal primers for $t c d A$ : (1) $t c d A i$ gene $\mathrm{F}$ : C gatgcggatccatgaacgagtctgtaaaag $($ Bam $\mathrm{HI}) \mathrm{R}$ : Tacttagctagcaccgaggacgcttttcg (Nhe I) (2) tcdAii gene F: Cggtgctagcggcatttgaagctaactcgt (Nhe I) R: Gtgagggccccaccaggtaccatctgat (Apa I) and (3) tcdAiii gene: F: ggtggggccctcactttgttagagatgataaag (Apa I) R: gtgcagctcgagttatttaatggtgtagcgaatatgc (Xho I)

\section{Polymerase chain reaction}

Different concentrations of primers 2.5, 5 and $10 \mathrm{pM}$ were used to optimize amplification using total DNA of Photorhabdus luminescens. Primers at $5 \mathrm{pM}$ concentration were found optimum and used in all further studies. Taq DNA polymerase, 10x assay buffer and mixed dNTPs were obtained from M/s Bangalore Genei Private Ltd., Bangalore. Eppendorf Master Cycler (5331) was used to run the PCR programme (Table 1).

\section{Gel elution of the PCR amplicon}

The Ferment as gel extraction kit was used to elute the different predicted size of $2.4 \mathrm{~kb}$, $2.7 \mathrm{~kb}$ and $2.4 \mathrm{~kb}$ in $t c d A i$, tcdAii and $t c d A i i i$ respectively from the agarose block as described in user's manual.

\section{Ligation of three fragments of $t c d A$ gene}

A total reaction volume of $25 \mu$ was set up for ligation by mixing the following components in a $0.5 \mathrm{ml}$ tube: Purified PCR fragments of tcdAi tcdAii and tcdAiii 5.0 $\mu \mathrm{l}$ each, 1OX ligation buffer $3.0 \mu \mathrm{l}$, PEG4000 solution $3.0 \mu \mathrm{l}$, BSA $0.5 \mu$, Deionised water upto $3.0 \mu \mathrm{l}$ and T4 DNA ligase $0.5 \mu$ l Ligation was carried out at $22^{\circ} \mathrm{C}$ for $16 \mathrm{hrs}$.

The ligated fragment was used for cloning in expression vector pET-32a (+).The ligated fragment and the vector pET-32a were simultaneously subjected to digestion with BamHI and XhoI restriction enzyme in separate reaction. $2.0 \mu \mathrm{l}$ of both insert and vector were run on 1.2 Percent agarose gel and the remaining sample was purified using Fermentas purification Kit. Ligation reaction was set at 1: $3(\mathrm{v} / \mathrm{v})$ vector to insert ratio and ligation was carried out according to manufacturer instructions using T4 DNA ligase, for overnight at $4^{\circ} \mathrm{C}$. Approximately $50 \mathrm{ng}$ of the insert was ligated in pET-32a (+) (Novagen) digested with BamHI and XhoI restriction enzymes and the recombinant vector was named as pET-32a (+) tcdA. construct pET-32a(+) -tcdA was transformed by heat shock into $E$. coli competent cells BL21 DE2. Standard techniques for these steps such as plasmid DNA preparation, ligation, competent cell preparation and transformation were followed, as described previously (Sambrook and Russell, 2001). Ampicillin-resistant colonies were grown until OD $600=0.4$ to 0.6 in $\mathrm{LB}$ medium containing $100 \mu \mathrm{g} / \mathrm{ml}$ of Ampicillin, at $37^{\circ} \mathrm{C}$ with agitation.

The plasmids were purified and analyzed for restriction enzyme digestion with Bam $\mathrm{HI}$ and Nhe-1, Nhe-1 and Apa-1, Apa-1 and Xho-1 to confirm the presence of tcdA. PCR amplification using $t c d A$ full length primer was also carried out to further confirm the 
clone. Confirmed clones were used further to optimize the expression of $t c d A$ in bacterial system

\section{Expression and purification of $t c d A$}

For expression of $t c d A$, the purified pET32a $(+)$ tcdA construct was transformed in $E$. coli BL21 (DE3) cells (Novagen, USA) by heat shock method. The selected E. coli clone showing expression of $t c d A$ was inoculated into $100 \mathrm{ml} \mathrm{LB}$ broth containing ampicillin $(100 \mu \mathrm{g} / \mathrm{ml})$ and grown at $37^{\circ} \mathrm{C}$ for $10-12 \mathrm{hrs}$ as pre-inoculum. $50 \mathrm{ml}$ of the pre-inoculum was inoculated to $500 \mathrm{ml}$ of $\mathrm{LB}$ medium containing ampicillin $(100 \mu \mathrm{g} / \mathrm{ml})$ and incubated on a shaker at $37^{\circ} \mathrm{C}$ until OD reached a value of 0.6 at $600 \mathrm{~nm}$. When the bacterial suspension reached an O.D value of 0.6 at $600 \mathrm{~nm}$, culture was induced with $0.5 \mathrm{mM}$ IPTG (iso propyl $\beta$ thiogalactopyranoside) to a final concentration and incubation was continued at $30^{\circ} \mathrm{C}$ for overnight in a shaker-incubator. The induced culture was harvested by centrifugation at $6000 \mathrm{rpm}$ for $12 \mathrm{~min}$ at $4^{\circ} \mathrm{C}$.

The cell pellet was suspended in $30 \mathrm{ml}$ of lysis buffer and was disrupted by sonication on ice bath for $15 \mathrm{~min}$, the cell debris was pelleted by centrifugation at $12000 \mathrm{rpm}$ for 10 min at $4^{\circ} \mathrm{C}$ and both the supernatant and the cell debris pellet were stored at $-80^{\circ} \mathrm{C}$ until tested.

Expressed protein was purified by chromatography through Ni-agarose (Invitrogen), from the insoluble phase of lysate using Guanidine hydrochloride $6 \mathrm{M}$ to dissolve the pellet, according to the manufacturer's protocol. Briefly, two $\mathrm{ml}$ of Ni-NTA resin was packed into a syringe, washed and equilibrated in 10 column volumes of deionized water, followed by 10 column volumes of binding buffer $(\mathrm{pH}=7.8$, K3(PO4) 50 mM， NaCl $400 \quad \mathrm{mM} ， \mathrm{KCl}$
100mM, $10 \mathrm{mM}$ Imidazole, 10\% Glycerol, $0.5 \%$ Triton $\mathrm{X}-100)$. The filtered supernatant of lysate insoluble phase through a $0.45 \mu \mathrm{m}$ membrane was loaded onto a Ni-NTA column and then washed with 10 column volumes washing buffer containing $20 \mathrm{mM}$ Imidazole. Target protein was eluted using an Imidazole gradient (100-500 $\mathrm{mM})$ in the binding buffer. Subsequently, the eluted solution containing protein was collected. The concentration of purified protein was determined by Bradford method. The purified $t c d A$ was analyzed by SDS-PAGE gel and Coomassie brilliant blue staining.

\section{Results and Discussion}

\section{Amplification and cloning of DNA coding for $t c d A$}

Amplification of $2.4 \mathrm{~kb}, 2.7 \mathrm{~kb}$ and $2.4 \mathrm{~kb}$ in tcdAi, tcdAii and tcdAiii respectively, followed by ligation of these fragment and ligated fragment was cloned successfully in the $\mathrm{pET} 32 \mathrm{a}(+)$ expression vector. The integrity of the constructed vector pET32a (+) tcdA was confirmed by restriction digestion analysis. The sequencing of constructed plasmid with full length primer $t c d A$ were performed (Plate 1 and 2).

\section{Expression and purification of tedA}

The $t c d A$ protein was expressed immediately after induction with IPTG. The expected recombinant fusion protein of $283 \mathrm{kDa}$ was detected after induction of the culture with IPTG. Most of it was found to be localized inside the inclusion bodies (pellet of cell lysate) in the cells. The maximum amount of tcdA was obtained overnight after induction by IPTG at $30^{\circ} \mathrm{C}$ with agitation (Plate-3). After purification of tcdA by Ni- NTA Affinity Chromatography, the yield of the purified solution was estimated by Bradford method about $0.350 \mu \mathrm{g} / \mathrm{ml}$ of culture 
Table.1 PCR amplification conditions employed for amplification of tcdA, tcdAi tcdAii and tcdAiii genes

\begin{tabular}{|c|c|c|c|c|c|c|c|c|c|c|}
\hline Stage & Step & \multicolumn{4}{|c|}{ Temperature $\left({ }^{\circ} \mathrm{C}\right)$} & \multicolumn{4}{|c|}{ Duration } & $\begin{array}{c}\text { No. } \\
\text { of } \\
\text { cycles }\end{array}$ \\
\hline 1 & Initial Denaturation & \multicolumn{4}{|c|}{94} & \multicolumn{4}{|c|}{$4 \min$} & 1 \\
\hline 2 & Denaturation & \multicolumn{4}{|c|}{94} & \multicolumn{4}{|c|}{$30 \mathrm{sec}$} & \\
\hline \multirow{2}{*}{3} & \multirow{2}{*}{ Annealing } & $t c d A i$ & tcdAil & tcdAiii & $t c d A$ & \multirow{2}{*}{\multicolumn{4}{|c|}{$30 \mathrm{sec}$}} & \\
\hline & & 55 & 60 & 58 & 58 & & & & & 330 \\
\hline \multirow{2}{*}{4} & \multirow{2}{*}{ Extension } & \multirow{2}{*}{\multicolumn{4}{|c|}{72}} & $t c d A i$ & tcdAii & tcdAiii & $t c d A$ & \\
\hline & & & & & & $2.5 \mathrm{~min}$ & $2.5 \mathrm{~min}$ & $2.5 \mathrm{~min}$ & $8 \mathrm{~min}$ & \\
\hline 5 & Final Extension & \multicolumn{4}{|c|}{72} & \multicolumn{4}{|c|}{$15 \mathrm{~min}$} & 1 \\
\hline 6 & Hold & \multicolumn{4}{|c|}{4} & \multicolumn{4}{|c|}{ infinity } & \\
\hline
\end{tabular}

Plate.1 PCR amplification of (1) tcdAi, (2) tcdAii and (3) tcdAiii, gene from genomic DNA using specific primer (M) marker

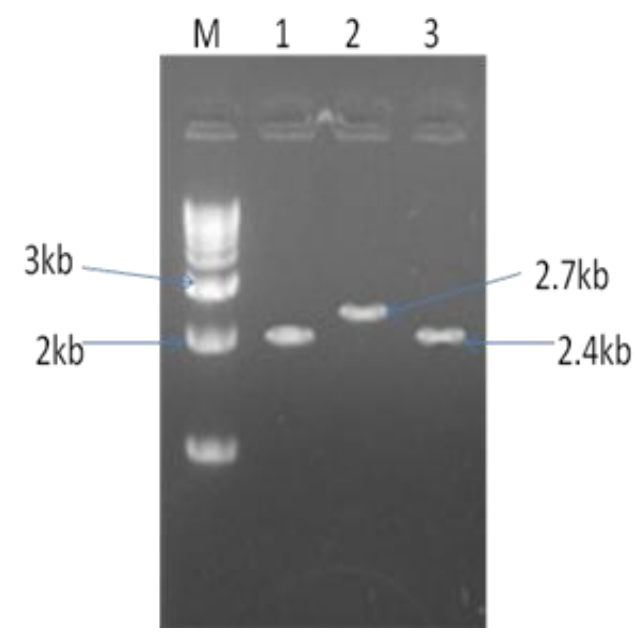

Plate.2 PCR amplification of (1) $t c d A$ gene using full length primer (M) marker

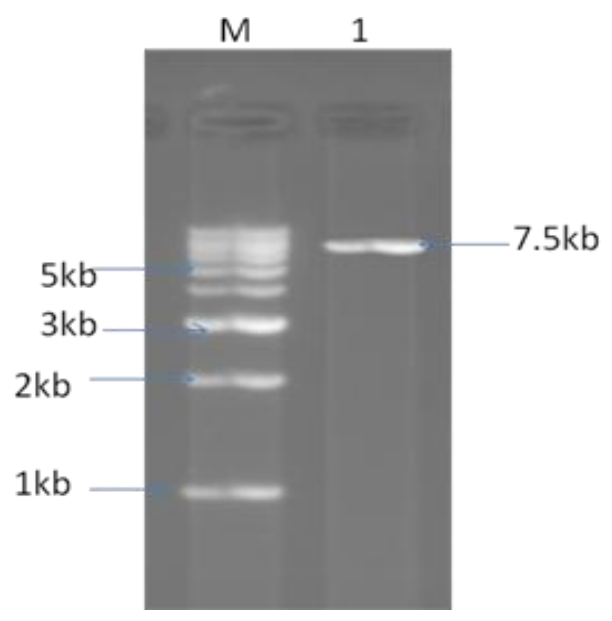


Plate.3 SDS PAGE analysis for expression of $t c d A$ gene

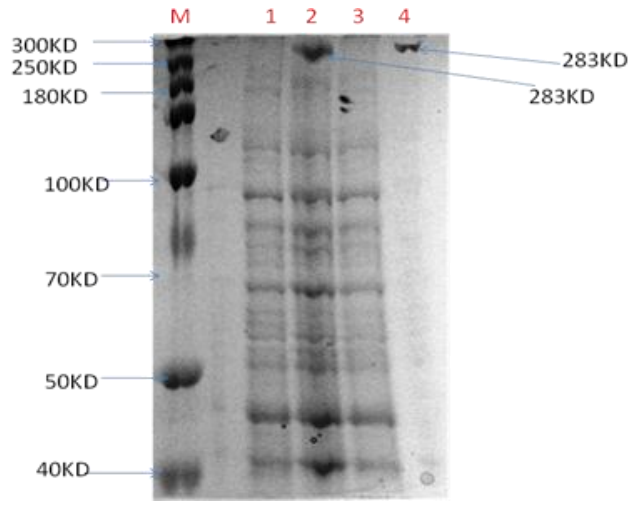

In this study the expression vector pET32a (+) was used to construct expressing vector, pET32a (+) tcdA. The pET System is the most powerful system yet developed for the cloning and expression of recombinant proteins in $E$. coli (Novagen's pET System Manual and Novagen, Technical Bulletin 009). Target genes are cloned in pET plasmids under control of strong bacteriophage $\mathrm{T} 7$ transcription and translation signals; expression is induced by providing a source of T7 RNA polymerase in the host cells. T7 RNA polymerase is so active that, when fully induced, almost all of the cell's resources are converted to target gene expression (Novagen's pET System Manual and Novagen, Technical Bulletin 009).

By transferring the plasmid pET32a (+) tcdA into $E$. coli BL21 DE3, expression was induced by the addition of IPTG. This vector encodes the His•Tag sequences that allow easy purification, quantification and detection of target proteins (Meng et al., 2009). His•Tag domain follows the cloning sites, allowing $\mathrm{C}$ terminal fusions by cloning in the appropriate continuous reading frame. The His $\bullet$ Tag sequence is very useful as a fusion partner for protein purification. His $\bullet$ Tag fusion proteins can be affinity purified under fully denaturing conditions (Novagen's pET System Manual and Novagen, Technical Bulletin 009).

In this study, BamHI and Xho-I cloning sites were chosen for insertion. Therefore, His $\bullet$ Tags sequences were incorporated in the expressed protein. These additional tags increased the size of the expressed protein. The restriction digestion and PCR results confirmed the integrity of the cloning. The $t c d A$ was purified successfully and this can be use for further studies. One of the most important toxic protein against different insect pest was made available by production of a recombinant $E$. coli expressing the $t c d A$ gene as a fusion protein to easy purification.

\section{Acknowledgment}

We acknowledge the Dr. Raj Bhatanagar, ICGEB New Delhi for providing Photorhabdus luminiscens culture.

\section{References}

Bird, A.F., and Akhurst, E.J., 1983. The nature of the intestinal vesicle in nematodes of the family Steinernematidae. Int. $J$. Parasitol., 13: 599-606.

Boemare, N.E., 2002. Biology, taxonomy and systematics of Photorhabdus and Xenorhabdus. In Entomopathogenic Nematology, pp. 35-56. Edited by R. Gaugler. New York, NY, USA: CABI Publishing.

Boemare, N.E., Akhurst, R.J., and Mourant, R.G., 1993. DNA relatedness between Xenorhabdus spp. (Enterobacteriaceae) symbiotic bacteria of entomopathogenic nematodes, and a proposal to transfer Xenorhabdus lumenescens to new genus, Photorhabdus Gen. Nov. Inter. J. Syst. 
Bacterial., 43:249-255.

Ehlers, L.E., 1991. Some contemporary issues in biological control of insects and their relevance to the use of entomopathogenic nematodes. In: Gaugler, Kaya (Eds.), Entomopathogenic Nematodes in Biological Control. CRC Press, Boca Raton, FL.

Ffrench-Constant, R., and Bowen, D., 1999. Photorhabdus toxins: Novel biological insecticides. Curr. Opin. Microbiol, 2: 284-288

Ffrench-Constant, R., Waterfield, N. and Daborn, P., 2003. Photorhabdus: towards a functional genomic analysis of a symbiont and pathogen. FEMS Microbiol. Rev., 26: 433-456.

Ffrench-Constant, R.H., Dowling, A. and Waterfield, N.R., 2007. Insecticidal toxins from Photorhabdus bacteria and their potential use in agriculture. Toxicon, 49: 436-451.

Georgis, R., and Manweiler, S.A., 1994. Entomopathogenic nematodes: a developing biological control technology. Agric. Zool. Rev. 6: 63-94

Koppenhofer, A.M., 2000. Nematodes. In: Lacey, L.A., Kaya, H.K. (Eds.), Field Manual of Techniques in Invertebrate Pathology. Kluwer, Dordrecht, the Netherlands, pp. 283-301.

Liu, S., Burton, T. Glancy, Z.S. Li, R. Hampton, T. Meade and D.J. Merlo, 2003. Insect resistance conferred by 283$\mathrm{kDa}$ Photorhabdus luminescens protein TcdA in Arabidopsis thaliana. Nat. Biotechnol., 21 (2003), pp. 1307-1313.

Martens, E.C., and Goodrich-Blair, H., 2005. The Steinernema carpocapsae intestinal vesicle contains a subcellular structure with which Xenorhabdus nematophila associates during colonization initiation. Cell. Microbiol, 7: 1723-1735.

Meng, F., Shen, C., He, Y., Miao, F. AND ZHANG, J 2009. Cloning and expression of three peptide-linked $\beta 2$-microglobulin molecules in Escherichia coli with an isocaudamer technique. Biotechnol. Lett, 31: 831-836.

Morgan, J.A.W., Sergeant M., Ellis D., Ousley M., and Jarrett P. 2001. Sequence Analysis of Insecticidal Genes from Xenorhabdus nematophilus PMFI296. Applied and Environmental Microbiol, Vol. 67, No. 5, p. 2062-2069

Pinheiro, V.B., Ellar, D.J. Expression and insecticidal activity of Yersinia pseudotubeculosis and Photorhabdus luminescens toxin complex proteins. Cell Microbiol. 2007, 9, 2372-2380.

Poinar, G.O.JR., 1990. Biology and taxanomy of Heterorhabditdae and Steinernematidae. In: Entomopathogenic nematodes in biological control. (Eds.) CRS Press. Boca Roton. Fl. PP. 23-61.

Sambrook, and Russell 2001. Molecular Cloning: A Laboratory Manual (3rd Ed.). Cold Spring Harbor Laboratory Press. ISBN 978-0-87969-577-4.

Sambrook, J., Fritsch EF, and Maniatis T 1989. Molecular Cloning: A laboratory Manual (2nd Edition). Cold Spring Harbor Laboratory, New York.

Thomas, G.M., and Poinar, JR, 1983. Amended Description of the Genus Xenorhabdus Thomas and Poinar. Int. J. Syst. Bacterial., 33: 878-879

Waterfield, N.R., Daborn, P.J.; FfrenchConstant, R.H. Insect pathogenicity islands in the insect pathogenic bacterium Photorhabdus. Physiol. Entomol. 2004, 29, 240-250.

\section{How to cite this article:}

Mulla, S.R., Shourabh Joshi and Joy Das. 2017. Isolation, Cloning and Expression of InsecticidalProtein-Encoding Gene tcdA from Photorhabdus luminescens in Escherichia coli. Int.J.Curr.Microbiol.App.Sci. 6(9): 1718-1724. doi: https://doi.org/10.20546/ijcmas.2017.609.212 